\title{
Juan Antonio Villacañas, Selected Poems, Translated by Michael Smith \& Beatriz Villacañas, Edited by Luís Ingelmo, Exeter: Shearsman Books, 2009, $166 \mathrm{pp}$.
}

Extensa, original y muy interesante es la obra poética creada por el toledano Juan Antonio Villacañas, autor poco y mal conocido en España y por supuesto fuera de ella. De ahí la importancia de cualquier antología de su producción literaria que propicie su conocimiento entre nosotros, y en la esfera internacional. Al propósito de difundir sus versos en nuestro país respondió en su día el libro de 2003 La poesía de Juan Antonio Villacañas, del que se ocupó Beatriz Villacañas, y que fue auspiciado por la Junta de Comunidades de Castilla-La Mancha. Ahora, y en el marco ya de facilitar la difusión foránea del autor, se inscribe la selección de versos que reseñamos, y que ha sido publicada en 2009, bajo el sello de Shearsman Books, en la localidad británica de Exeter.

Selected Poems consta, como declaradamente se anuncia en el título, de una representativa selección de textos poéticos en edición bilingüe español-inglés, y que han sido trasladados a este último idioma por Michael Smith y por Beatriz Villacañas, poetas ambos y expertos en versiones de poesía. Él trasladó composiciones de autores españoles e hispanoamericanos al inglés, desde Góngora y Quevedo hasta Miguel Hernández, pasando por Bécquer y Rosalía de Castro. Ella, por su parte, a autores ingleses al español, entre ellos Shakespeare y W. B. Yeats.

Que un poeta sea traducido por otro poeta suele ser garantía de éxito en la tarea, éxito entendido como aproximación, lo más fidedigna posible, a los textos de partida. Pero en el supuesto que nos ocupa podemos asegurar que los resultados de las versiones son más plausibles aún, porque en Beatriz Villacañas concurre, a mayores, un conocimiento directo de la idiosincrasia de su progenitor que va acompañado de un celo, nunca excesivo, en el respeto máximo a su palabra más genuina. De ahí que cuando uno lee estos traslados no sólo constata que son fidedignos desde la vertiente lingüística, y desde sus aspectos formales, cualesquiera que sean, sino que se da cuenta también de que en aquellos trances, y no son pocos, en los que el traductor se halla en la encrucijada de decidirse acerca de sentidos varios de un poema, se acerca más a ellos, los atisba mejor porque dispone de los parámetros biográficos que le proporcionan una privilegiada situación para captarlos, cuando no para adivinarlos.

Esta colección de Selected Poems de Juan Antonio Villacañas pone al alcance de los lectores de habla inglesa el perfil esencial de un poeta muy singular. Y es que, por edad, bien pudiera haber sido incluido en la nómina de los de la primera generación de posguerra, en la que figuran autores como Eugenio de Nora y Gabino Alejandro Carriedo, nacidos en 1923. Pero para ser contemplado en dicha leva habría tenido que adelantar su comparecencia pública, como lírico, en algunos años. Por otra parte, como su bibliografía literaria comienza en la década siguiente, acaso hubiera podido ser incorporado a la extensísima relación de los creadores del medio siglo. Aunque ahí nos topamos con otra dificultad, la de que en la crítica se impuso un reducido elenco de poetas representativos de la poesía de esos años, los alojó bajo el marbete de grupo o generación del 50, y difundió con éxito sus emparentables poéticas como canónicas en esa época medial del siglo XX. Y la poesía de Juan Antonio Villacañas no se ajustaba para nada a los parámetros anotados por y para tales autores.

Dejado al margen de la atención crítica prestada a los de la primera generación poética de posguerra, y a los de la segunda también, es decir a los poetas conocidos comúnmente como del cincuenta, Juan Antonio Villacañas unió otro marginalismo, el de decidir centrar su vida en tierra toledana, realizando su obra lírica en ese contexto provincial. Y esa decisión puede no ser la más acertada si uno pretende figurar en el candelero literario, pero al menos favorece el recorrido de una trayectoria poética poco o nada tributaria de tendencias y de seguidismos dominantes. En su virtud, su obra se creó desde la independencia creadora más absoluta, lo que permite diferenciarla nítidamente de las de los coetáneos, tanto en asuntos poetizados como en las formas elegidas.

Al leer los poemas de Juan Antonio Villacañas, el avezado en poesía va comprobando cómo por su temática no se parece a nadie, y en el tratamiento de la misma tampoco. La voz del 
poeta toledano es distinta y suena distinto, siendo muy sorpresivo su punto de vista y a veces la extrañeza que logra al expresarlo. Remito a ejemplos como los versos con los que puso fin a uno de los textos, "Olor a carne", de su conjunto de 1973 Rebelión de un recién nacido:

Resistid, hombres solos,

los odios, los halagos, las guerras de los hombres.

¡Pero morid de risa!

Así de desmitificador se muestra Villacañas al poetizar un tema tan severo como el de la soledad y el de otras situaciones que comporta el vivir. Y el tema del "amor constante más allá de la muerte" ha de pasar por el trago de parecida lente desmitificadora, de modo que los puntos clave de los celebérrimos endecasílabos quevedianos con los que finaliza su soneto "Cerrar podrá mis ojos..." se contrapuntean de ese tenor:

("Mas tendrán sentido.")

Pues tiene mucha más gracia todavía. Más gracia que sentido.

Polvos enamorados, ¿dónde estáis?

El tema de Dios propicia también a Villacañas el logro de sesgos inesperadamente llamativos, como en los versos culminantes del poema del antecitado libro que lleva por título "Ir matando a dos manos":

De todos modos, Dios, siempre me está esperando

para darme un destino,

o un trabajo de muerto.

Esta temática adquiere su punto más álgido en el poema "Rebelión de un recién nacido", el cual da título a la obra. Me atrevo a afirmar que su autor ha conseguido en estos versos atisbos de problematicidad teológica que muy pocos poetas son capaces de suscitar. Basten dos pasajes como prueba. Traslado el primero:

Y mi incredulidad es tanto Dios, que estoy casi seguro

de poder adorarle.

Necesitaríamos muchísimas páginas para plantear y para discurrir acerca de cuanto sugieren estas dos líneas conteniendo diversos hallazgos conceptuales. Pero sigamos, porque unos versos después se continúa urgando en complejidades teologales que, como anteriormente, estriban en concentrar, en un reducido radio textual, un cúmulo de posibles y sesudas reflexiones desde la ironía:

Los niños y las arañas tienden a Dios sus redes.

Pero Dios no se rinde, no puede caer en la trampa.

Y sigue pisando redes y niños y arañas con la suavidad del aire, con la suavidad del aire de un Dios padre.

En ese mismo libro, Rebelión de un recién nacido, encontramos un poema de veras impresionante, "Breve historia de una cacería". Se parte en él de una concepción proanimalística de máximos, y muy llamativa para la época. El posicionamiento contrario a la caza se poetiza imaginándose el hablante "en la piel" del jabalí abatido a balazos y después comido por quien le abatió y sus amigos. El locutor poemático se siente convertido en la víctima y a la vez ve al que caza en la pieza cazada. Esta perspectiva traduce la tesis de la coequiparación de los animales con el hombre. Pero el texto da aún más de sí, porque entreabre la puerta a cuestiones que podrían concernir a la religión, y en concreto a la cristiana. Algunos versos cabría que se descifrasen desde esa perspectiva, así los siguientes: 
Disparo ciegamente hacia la eternidad.

No sé por qué, me quiero transformar

en alimento.

Y el jabalí se vuelve a nuestra vida

como un dios animal resucitado.

En abono de ese posible desciframiento, aduzco que en la obra del autor se leen de vez en vez puntos de vista conteniendo ironizaciones de calado religioso. En su conjunto de 1996 A muerto por persona, por ejemplo, un endecasílabo del poema titulado "Carta emocionada de Juan Amor de Velasco" ofrece la disyuntiva "entre el antiguo Dios y un dios moderno". Y en el texto "La brújula", del mismo conjunto, podemos leer otra línea no menos punzante: "por eso Dios está desorientado." Estas muestras unidas a las anteriores, hablan por sí solas de que expresiones poéticas como las señaladas impregnan de interesantísima sustancia conceptual la poesía de Juan Antonio Villacañas, una poesía que no resulta menos merecedora de atención si se valora la vertiente de sus contornos y ritmos formales.

Poeta que ha desarrollado cauces discrecionales propios en múltiples composiciones, Juan Antonio Villacañas salió siempre muy airoso a la hora de encauzar su poesía en estrofas regladas, sobresaliendo en la factura de décimas y sobre todo de sonetos, de los que ya hay notables ejemplos en la más temprana de sus etapas literarias, como lo acreditan los pertenecientes a su Marcha destriunfal (1960). Sin embargo, en lo que más se distingue es en haber cultivado la lira con intensidad y pericia, convirtiéndose en el poeta hispánico contemporáneo más fiel a una fórmula rítmica que ha repristinado para la poética española finisecular.

Acaso no sea ajeno Garcilaso a que otro toledano haya cogido el testigo del empleo de este metro que el poeta renacentista introdujo en la poesía de su tiempo. En cualquier supuesto, desde la lírica renacentista no se había dado un supuesto semejante de apego a esta pauta métrica, a la que Juan Antonio Villacañas rindió pleitesía en su extenso poema Homenaje a la lira en larga sobremesa con Luciano (1993), y continuó prodigándose en esa línea en libros sucesivos, así en el citado A muerto por persona, y asimismo en Al margen de lo transitable (1996), Sublevación de la melancolía (1997), Sandemonio en la gloria (1998), y Balbuciendo (La llaga en la tierra) (1999).

José María Balcells 